\title{
Bluetongue virus in Europe: The current epidemiological situation
}

\author{
WIESŁAW NIEDBALSKI
}

Department of Foot and Mouth Disease, National Veterinary Research Institute, Wodna 7, 98-220 Zduńska Wola, Poland

\section{Niedbalski W. \\ Bluetongue virus in Europe: the current epidemiological situation}

Summary

The article reviews the history of BT occurrence in Europe and its present status. It describes the distribution of BT in Europe before 1998, the emergence of BTV in southern and eastern Europe in 1998-2006 and the epidemiology of BT in north-western Europe after 2006. Up to 1998, sporadic cases of BT were noted in Cyprus, on the Iberian Peninsula and on several Greek islands. However, since 1998, probably due to climatic changes, BTV has spread northwards into the Mediterranean Basin, where five BTV serotypes $(1,2,4,9$ and 16) have been identified. In August 2006, BTV passed for the first time latitude $50^{\circ} \mathrm{N}$, and BT outbreaks caused by BTV serotype 8 occurred in the Netherlands, Belgium, Germany, France and Luxembourg. Mass vaccination campaigns implemented in Europe in the spring of 2008 quickly limited the spread of disease caused by BTV-8, and it was eradicated by 2011. However, after a 3-year break, in September 2015, BTV-8 re-emerged in Europe, in central France, and subsequently spread throughout the entire country. In the following years, BTV-8 outbreaks were found in Switzerland, Germany, Belgium and Spain. In addition to BTV-8 outbreaks, BTV serotypes 1, 2, 4, 9 and 16 have recently circulated in Europe. As revealed by phylogeographic inference, the recent spread of BTV in Europe is a consequence of climatic, landscape and vertebrate host factors

Keywords: bluetongue, epidemiology, Europe

Bluetongue (BT) is a vector-borne viral disease of ruminants, including sheep, goats and cattle that induces variable clinical signs depending on the species and breed (12). The disease is caused by the bluetongue virus (BTV), which is a member of the genus Orbivirus within the family Reoviridae (16) and is transmitted by biting midges of the genus Culicoides (3). BTV is a small icosahedral virus (of about $70 \mathrm{~nm}$ in diameter) with a ten-segmented, double-stranded RNA (dsRNA) genome (25). Each of the ten segments codes for at least one of ten distinct viral proteins, seven of which are constructed components of the virus particle, and three of which are non-structural. The inner capsid of BTV is composed of five polypeptides: three minor proteins (VP1, VP4 and VP6) and two major proteins (VP3 and VP7) (4). The outer capsid is composed of two major viral proteins, VP2 and VP5, which determine the antigenic variability of BTV (20). The most common signs of the disease include fever, catarrhal stomatitis, rhinitis, enteritis and lameness. The mortality rate varies from $0 \%$ to $30 \%$, but may reach as high as $75 \%$ (14). On the basis of serotype-specific virus neutralization assays, 27 immunologically distinct serotypes (BTV1 to BTV27) have been identified worldwide (16). BT has a significant economic impact, mainly due to its effect on animals (morbidity, mortality, reproductive failure, reduction in milk yield and weight gain) and, most of all, to the disruption of international trade in animals and animal products (21). BTV is endemic in many tropical, sub-tropical and temperate regions of the world (America, Australia, Africa and some regions of Asia), between latitudes $40^{\circ} \mathrm{S}$ and $53^{\circ} \mathrm{N}$, during times of the year that are optimal for vector activity (13). The article reviews the history of BT occurrence in Europe and its present status. It describes the distribution of BT in Europe before 1998, the emergence of BTV in southern and eastern Europe in 1998-2006 and the epidemiology of BT in Europe after 2006.

\section{BT epidemiological situation in Europe before 2006}

Historically, Europe has experienced only sporadic incursions of BT, involving a single-virus serotype on each occasion. Although cases of BT have occurred regularly in Cyprus since at least 1924, BTV caused only two outbreaks elsewhere in Europe before 1998: a major outbreak of BTV-10 on the Iberian Peninsula between 1956 and 1960 and a smaller outbreak of BTV-4 
Tab. 1. Occurrence of BT in Europe, 1998-2005

\begin{tabular}{|l|c|c|}
\hline \multicolumn{1}{|c|}{ Country } & Year of first outbreak & BTV serotype(s) \\
\hline Albania & 2002 & 9 \\
\hline Bosnia-Herzegovina & 2002 & 9 \\
\hline Bulgaria & 1999 & 9 \\
\hline Croatia & 2001 & 9,16 \\
\hline Cyprus & 2003 & 16 \\
\hline North Macedonia & 2001 & 9 \\
\hline France (Corsica) & 2000 & $2,4,16$ \\
\hline Greece & 1998 & $1,4,9,16$ \\
\hline Italy & 2000 & $1,2,4,9,16$ \\
Kosovo & 2001 & 9 \\
\hline Montenegro & 2001 & 9 \\
Portugal & 2004 & 2,4 \\
\hline Serbia & 2001 & 9 \\
Spain & 2000 & 2 \\
Turkey & 1998 & $4,9,16$ \\
\hline
\end{tabular}

on several Greek islands in the Aegean in 1979-1980 (27). The massive mortality in Iberia demonstrated that BTV incursions into southern Europe were capable of supporting the transmission of BTV and that European livestock were highly vulnerable to the virus. Despite the severity of the BTV-10 outbreak, the virus remained an infrequent visitor to Europe for most of the twentieth century. This situation changed dramatically from 1998, when BTV serotype 9 was detected on several Greek islands close to the Anatolian Turkish coast. Over the following three years, it spread rapidly northwards and westwards in the Mediterranean Basin (Turkey, Bulgaria, Serbia, Montenegro, Kosovo and Macedonia), and was followed by incursions of BTV-1, BTV-2, BTV-4 and BTV-16 (Tab. 1). The introductions of BTV serotypes 1,9 and 16 were probably attributable at least in part to animal movements along the Eurasian ruminant street, a contiguous region with high densities of ruminants stretching from India and Pakistan through Afghanistan, Turkey, Iraq and Iran to the southeast Europe (24) The strain of BTV-1 detected in Greece in 2001 was similar to isolates from the far East and probably entered via the near Middle East (15). On the other hand, the strain BTV serotype 4 identified in Greece in 1999 was closely related to the strain recorded in the 1960s and 1970s from Cyprus and Turkey (2). Moreover, BTV-2 entered Tunisia in 1999, spreading to Algeria and Morocco in 2000 and then onwards into the western and central Mediterranean islands and mainland Italy. Afterwards, between 1998 and 2005, BTV entered Europe from at least two origins and spread up to $800 \mathrm{~km}$ further north in Europe than ever before (29). During this period over one million sheep died or were culled due to BTV in twelve European countries and Israel (19). Undoubtedly, the spread of the virus in those areas was affected by various factors, including the recent changes in European climate (increase in the mean annual temperature and humidity), which have allowed increased virus persistence during winter, the northward expansion of Culicoides imicola and, beyond this vector's range, transmission by indigenous European Culicoides species - thereby expanding the risk of transmission over larger geographical regions $(1,19,28)$.

\section{BTV outbreaks in Europe in 2006-2019}

In the summer of 2006, for the first time, the BTV crossed latitude $50^{\circ} \mathrm{N}$, and BT outbreaks caused by BTV serotype 8 occurred in north-western Europe: the Netherlands, Belgium, Germany, France and Luxembourg (28). The first cases of BTV-8 were identified in the Netherlands, where 456 outbreaks were reported during 2006. Then the virus spread to Belgium (695 outbreaks), Germany (885 outbreaks), northern France (6 outbreaks) and Luxemburg (5 outbreaks) $(10,29)$. The origin of this BTV-8 strain, as well as the mode of its introduction into Europe, is still undetermined (17). Sequence genome alignments revealed its close similarity to a BTV-8 strain isolated in subSaharan Africa (10), suggesting African origin. In 2007-2008, the BT situation changed for the worse, BTV-8 spread to the other regions of Europe, and the number of outbreaks increased rapidly (more than 50000 cases of BTV-8 were reported). However, the implementation of compulsory BT vaccination programmes in Europe in the spring of 2008 resulted in reduction of BTV-8 cases from about 50000 in 20072008 to 350 in 2009 and 19 in 2010 . The last case of BT caused by BTV-8 was reported in May 2011 in north Sardinia (Italy) (http://eubtnet.izs.it/btnet.reports/ BTV8.htlm). Subsequently, disease caused by BTV-6, BTV-11 and BTV-14 strains, genetically similar to live modified vaccine strains, has been noted in northern Europe $(6,7,18)$. BTV-6 and BTV-11 emerged in 2008 in the same area where BTV-8 emerged in 2006 (in the Netherlands and Belgium). Fortunately, only a very limited spread of BTV-6 and BTV-11, without clinical signs, was reported in the field in 2008, and, as in the case of BTV-16 in Corsica, both these BTV strains have no longer been detected. BTV-14 was detected for the first time in 2011 in Russia and in 2012 in Poland (18). This serotype was present in Poland until 2014, and then no further cases were reported. The introduction origins of these vaccine strains are still unknown. After a 3-year break, in September 2015, BTV-8 re-emerged in Europe, in central France on a cattle and sheep farm in the Allier department, and subsequently spread throughout the entire country $(10,23)$. How BTV-8 persisted in areas that were thought to have been free of virus transmission remains unknown, although it has recently been reported that a low-level circulation of BTV-8 occurred in France prior to its detection in 2015 (5). However, there were observations suggesting that changes had occurred in the epidemiology of the re-emerging strain of BTV-8. Whereas the 2007-2009 
BTV-8 strain caused widespread clinical signs in cattle and sheep, the re-emerging BTV-8 strain caused only mild clinical signs. Moreover, there has been evidence of reduced viremia, pathogenicity and vector competence in the re-emerging BTV-8 strain in sheep (8). In addition, the rate of spread of the virus in France appeared slower than that of BTV-8 from the previous epizootics. Genetically, the re-emerging BTV-8 strain differs from the 2006 BTV-8 strain in just 11 amino acids occurring in segments $1,4,8,9$ and 10 . The high degree of amino acid similarity between the two BTV-8 strains underpins the hypothesis that it was not a new introduction of BTV-8 (23). A key point of interest in the outbreak assessment was the increased trans-placental transmission of the re-emerging strain of BTV-8 in cattle (4). Trans-placental transmission is of interest as a possible mechanism of over-wintering of the virus in the absence of midges in northern Europe, but this increase also means that the economic impact of the re-emerging BTV-8 strain may be underestimated. There has been some further information on the clinical implications. Thus, healthy calves which are PCR positive have been detected. Furthermore, a recent modelling study on the re-emerging BTV-8 strain estimated the probability of vertical transmission at $56 \%$ in unvaccinated heifers infected late in gestation based on PCR pre-export test data obtained from June to December 2016 in France (4). There is some evidence that the vector competence of Culicoides sonorensis biting midges is reduced for the re-emerging BTV-8 strain compared to that for the 2006-2009 strain (16). The total number of BTV-8 outbreaks in France since 2015 has been estimated at 3138: there have been 143, 402, 1396, 653 and 544 outbreaks in 2015, 2016, 2017, 2018 and 2019 respectively (5, 26). On $23^{\text {rd }}$ October 2017 , a BTV-8 outbreak was confirmed in cattle in the Basel-Landschaft canton in northwestern Switzerland, returning, similarly in cattle, in September 2018 (https://healthmap.org/ promed $/ \mathrm{p} / 105)$. The cases in cattle were reportedly subclinical, detected within the framework of an active surveillance programme. Moreover, four BTV-8 outbreaks were recorded in sheep, the first starting on $12^{\text {th }}$ October 2018 , followed by three more on period indicated in brackets a sheep farm, starting on $16^{\text {th }}$ and $31^{\text {st }}$ October and $7^{\text {th }}$ November 2018. Different from the outbreaks in cattle, the disease cases in sheep were identified by clinical signs, which were confirmed by laboratory diagnostics. In total, as of $1^{\text {st }}$ February 2019,79 outbreaks caused by BTV serotype 8 have been reported in Switzerland. In France, apart from outbreaks of BTV-8, disease caused by BTV serotype 4 was detected in Corsica in 2016 and in mainland France, adjacent to the Swiss border, in November 2017 (22). The results of phylogenetic analysis and epidemiological data suggest that BTV-4 has been introduced to mainland France from Corsica or Italy, where BTV-4 outbreaks were reported in the summer and autumn of 2016. This was the first report of the introduction of BTV-4 in mainland France. This genetically distinct reassortment strain of BTV-4 was identified in 2014 in the Balkan countries (Croatia, Greece, Bulgaria, Romania, Slovenia), during 20142016 in mainland Italy and in the years 2016-2017 in Sardinia. In 2014, BTV-4 outbreaks were also reported in Spain and Portugal. In addition to BT outbreaks caused by serotypes 8 and 4, BTV-1, 2 and 16 have been reported in parts of the Mediterranean Basin. BTV-1 is circulating in France (Corsica), Italy, Spain and Portugal. BTV serotype 16 was confirmed in September 2017 in Greece and is currently circulating on the Greek islands of Samos, Lesbos and Dodecanese. The spread of BTV serotypes 1, 3, 4 and 8 in Europe in the period from 2006 to 2019 is shown in Figure 1.

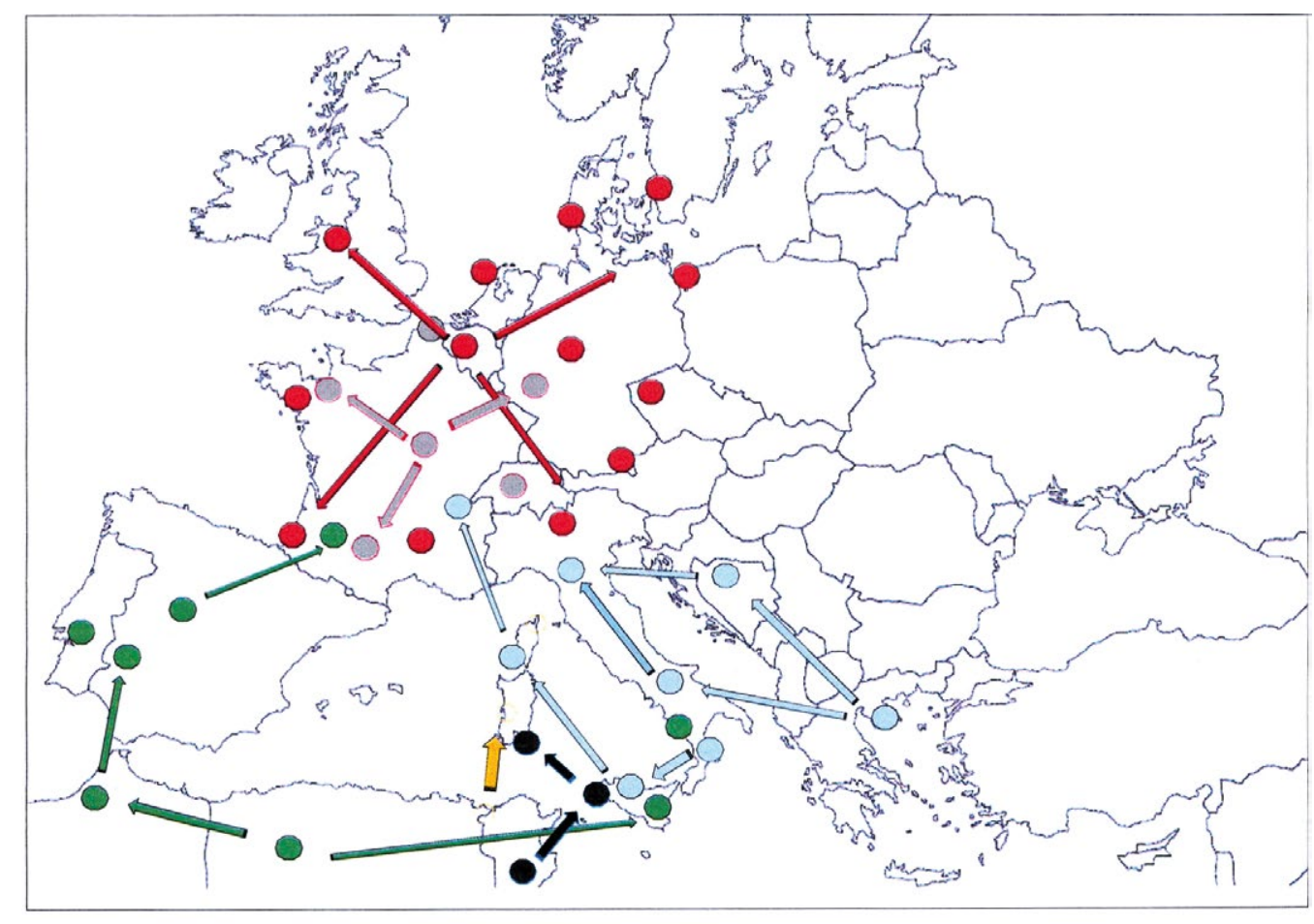
- 2007)
BTV-1 W (2011

- 2013)
BTV-4 E (2014

- 2019)
BTV-8 (2015

2019)
BTV-3 W (2017 2018)

Fig. 1. BTV spread from 2006 to 2019. Occurrence of BTV serotypes and strains during the

Explanations: E - Eastern strain; W - Western strain (modified, according to Kundlacz et al. (10)) 


\section{BT epidemiology in Europe in 2020-2021}

In 2020, 48 new outbreaks of BTV-8 were reported in France via Animal Disease Notification System (ADNS) (https://ec.europa.eu/food/animals/animalsdiseases/not-system_en). All these reports were confirmed as clinical cases with affected animals showing signs, such as depression, anorexia, pyrexia, congestion of the mucus membranes and abortion. All those outbreaks occurred in the southwestern regions of the country (Pyrenees-Atlantique, Ariege, Haute-Pyrenees, and Haute-Garonne), bordering Spain to the south. In Switzerland, the last BTV-8 outbreak was confirmed on $29^{\text {th }}$ October 2020 in the municipality Bassersdorf in the canton of Zurich. The animal did not show any clinical signs, but was detected through an annual surveillance programme, following sampling at the slaughterhouse. This was the first case reported in Switzerland since March 2020. On 12 ${ }^{\text {th }}$ December 2018, the German authorities confirmed a case of BTV-8 in cattle in the district of Rastatt in Baden-Württemberg, Germany. This was the first case of BT in Germany since November 2009. Then, on $29^{\text {th }}$ March 2019, a BTV-8 outbreak was reported in south-western and western Germany as part of a surveillance programme in this region, with the first outbreak detected in December 2018. Outbreaks in these regions of Germany along the borders with France were not unexpected, given the disease status of France. Since this BTV outbreak, the reporting of BTV-8 has fallen, and since the beginning of April 2019 there have been four outbreaks of BTV-8 in Germany, all in the south-west and all reported to OIE as sub-clinical infection (www.oie.int/wahis 2/ public/wahid.php/Diseaseinformation/WI). In 2020, two outbreaks of BTV-8 were reported on $14^{\text {th }}$ October in two regions, Trier-Saarburg and Merzig-Wadern, both very close to the border with Luxemburg. The last

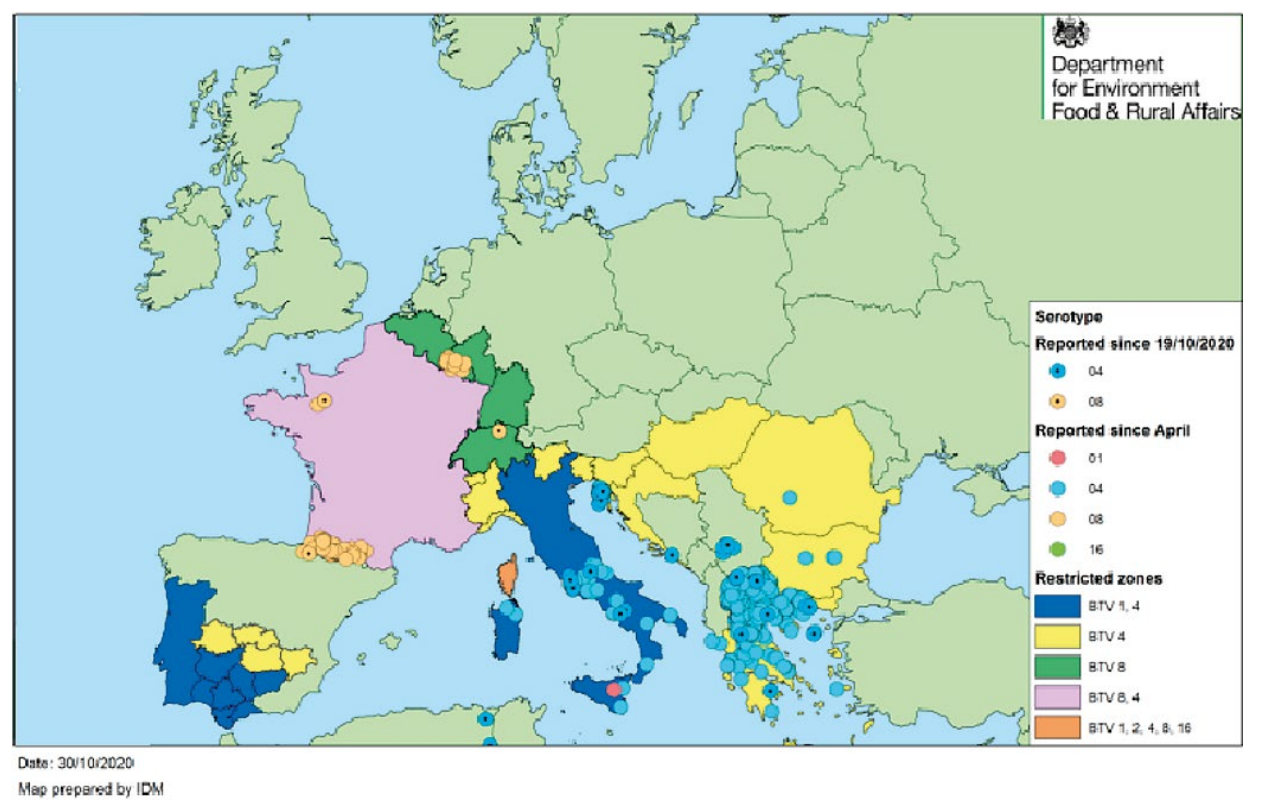

Fig. 2. BT in Europe as of $30^{\text {th }}$ October 2020. (modified, according to: https://www. gov.uk/government/publication/bluetongue-virus-in-europe) outbreak of BTV-8 prior to this was in February 2020. By the end of that year, 59 outbreaks of BTV-8 were reported in Germany (Baden-Württemberg, Saarland, Rhineland-Palatinate Landers, Trier-Saarburg and Merzig-Wadern). Most of them occurred in the southwestern part of the country, close to the borders with France and Switzerland (https://www.agriculture.gov. ie/bluetongue/). In addition, an outbreak of BTV-8 was detected on $14^{\text {th }}$ February 2019 in a cattle holding in the Luxembourg region of southern Belgium, and as of $1^{\text {st }}$ September 2020 five BTV-8 outbreaks have been reported (http://www.gov.uk/government/publications/ bluetongue-virus-in-europe). Furthermore, a single case of BTV-8 was confirmed on $21^{\text {st }}$ October 2020 in Spain in the Elizondo region in the north, with one animal in a herd of 80 cattle affected. The emergence of BTV-8 in northern Spain was not unexpected in view of the cluster of cases just north of the border, in southern France. However, it is worth noting that, as the Pyrenees are such a major biogeographical barrier, it is unlikely that even a single infected adult midge could have made it over such a high mountain range by flight. The emergence of BTV-8 in cattle in Spain is more likely to have been spread via a "midge baton" of transmission from one cattle herd to the next cattle herd over the Pyrenees. This report of BTV-8 in Spain is the first to have occurred since the 2015 re-emergence of BTV-8 in France. In 2020, a total of 70 outbreaks of BTV-8 were found in Europe: 48 in France, 11 in Luxembourg, 5 in Belgium, 3 in Switzerland, 2 in Germany and 1 in Spain. Apart from BTV-8, virus serotypes 1, 2, 4, 9 and 16 have been circulating in Europe (Fig. 2). In 2020, BTV-4 continued to spread widely across South-Eastern Europe, with several outbreaks being reported in Greece and in the Republic of North Macedonia and continued reports from Italy and Romania. In October 2020, both Bulgaria and Croatia reported cases of BTV-4 for the first time that year. Romania reported one new outbreak of BTV-4 in backyard sheep premises in the south-western region of Vilcea. Croatia reported BTV-4 for the first time since 2017 - four cases were found in the Istria region, all in individual cattle which tested positive following active surveillance. There were the first new cases of BTV-4 since 2014 in Bulgaria. As revealed by phylogeographic inference, the recent changes in BTV spread in Europe are a consequence of climatic, landscape and vertebrate host factors.

A map of BTV-restricted zones in Europe (as of $21^{\text {st }}$ September 2021) and virus serotypes cir- 


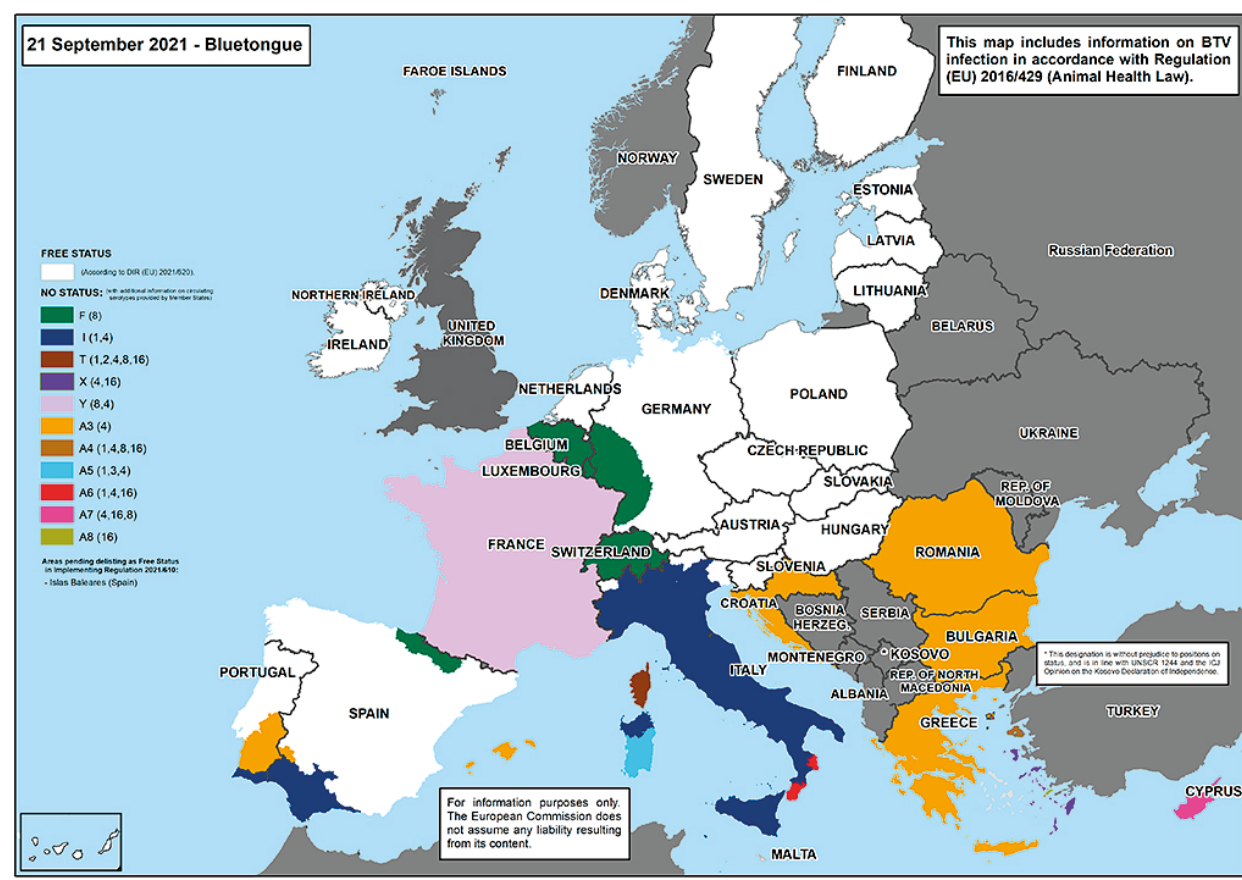

Fig. 3. Bluetongue - restricted zones in Europe as of $21^{\text {st }}$ September 2021 (http:// ec.europa.eu/food/animal/diseases/controlmeasures/bt_restrictionzones-map.jpg)
In conclusion, it can be stated that BT and the virus that causes this disease evolve, and constant monitoring of $\mathrm{BT}$ is essential for its effective control. As revealed by phylogeographic inference, the recent spread of BTV in Europe is a consequence of climatic, landscape and vertebrate host factors. The best strategic option for control of clinical BT outbreaks in European endemic areas is vaccination of susceptible animals with inactivated vaccines to protect them against the disease and to exclude the possibility of reversion to virulence of the vaccine viruses and reassortment between the vaccine and field strains of the virus $(21,23)$. Veterinary authorities and legislators throughout Europe would do well to take note of these recent, considerable

culating in each zone is presented in Figure 3: Zone Y - BTV-8 and 4, France: mainland territories of the country, Zone I-BTV-1 and 4: Italy (whole territory), Croatia: the island of Lastovo in the Split-Dalmatia region, Spain: the autonomous community of Andalucia (Cadiz and Malaga provinces), in Granada province Mortil region, Huelva province, in Cordoba province - Pasadas region, in Sevilla province - Cantillana, Carmona, Ecija, Lebrija, Marchena, Osuna, Sanlucar la Mayor, Sevilla and Utrera regions, Portugal: Algarve region, Zone T - BTV-1, 2, 4, 8 and 16, France: Department de Haute-Corse and Department de Corsedu-Sud, Zone X - BTV-4 and 16, Greece: the islands of Dodecanese and Samos, Zone A3 - BTV-4, Greece: the entire territory of Greece except for the regional units of the Cyclades islands and the island of Chios, Bulgaria: whole territory, Romania: whole territory, Croatia: whole territory, Spain: Baleares islands and the region of Jerez de los Caballeros in Badajoz Province in Autonomous Community of Extremadura, Italy: northern part of country (Valle d'Aosta, Province of Bolzano and Friuli Venezia Giulia region), Portugal: region of Alentejo, Zone A4 - BTV-1, 4, 8, 16, Greece: the island of Lesbos, Zone A5 - BTV-1, 3, 4, Italy: Sardinia island, Zone A6 - BTV-1, 4, 16, Italy: Crotone and Calabria regions, Zone A7 - BTV-4, 16 and 8, Cyprus: whole territory, Zone A8 - BTV-16, Greece: the islands of Kos, Ikaria, Samos, Dodecanese and Lesbos, Zone F - BTV-8, Belgium: all territory, Germany: Saarland, Rhineland-Palatinate Landers, administrative divisions of Baden-Württemberg, administrative divisions of Hessen and North Rhine-Westphalia, Luxembourg: whole territory, Spain: autonomous community of Navarra, Pais Vasco and Aragon, Switzerland: whole territory.

\section{References}

1. Baylis M.: The re-emergence of bluetongue. Vet. J. 2002, 164, 5-6

2.Breard E., Sailleau C., Nomikou K., Hamblin C., Mertens P. P. C., Mellor P. S., El Harrak M., Zientara S.: Molecular epidemiology of bluetongue virus serotype 4 isolated in the Mediterranean Basin between 1979 and 2004. Virus Res. 2007, 125, 191-197.

3. Carpenter S., Groschup M. H., Garros C., Felippe-Bauer M. L., Purse B. V. Culicoides biting midges, arboviruses and public health in Europe. Antiviral. Res. 2013, 100, 102-113.

4. Courtejoie N., Bournez L., Zanella G., Durand B.: Quantifying bluetongue vertical transmission in French cattle from surveillance data. Vet. Res. 2019, 50,34 .

5. Courtejoie N., Durand B., Bournez L., Gorlier A., Breard E., Sailleau C., Vitour D., Zientara S., Baurier E., Gourmelen C., Benoit F., Achour H., Milard C., Poliak S., Pagneux C., Viarouge C., Zanella G.: Circulation of bluetongue virus 8 in French cattle, before and after the re-emergence in 2015. Transbound. Emerg. Dis. 2018, 65, 281-284.

6. De Clercq K., Mertens P., De Leeuw I., Oura C., Houdart P., Potgieter A. C. Maan S., Hooyberghs J., Batten C., Vandemeulebroucke E., Wright I. M., Maan N., Riocreux F., Sanders A., Vanderstede Y., Nomikou K., Raemaekers M., Bin-TarifA., Shaw A., Henstock M., Breard E., Dubois E., Gastaldi-Thiery C., Zientara S., Verheiden B., Vandenbussche F.: Emergence of bluetongue serotypes in Europe, part 2: the occurrence of a BTV-11 strain in Belgium. Transbound. Emerg. Dis. 2009, 56, 355-361.

7. Eschbaumer M., Hoffmann B., Moss A., Savini G., Leone A., Konig P., Zemke J., Conraths F., Beer M.: Emergence of bluetongue virus serotype 6 in Europe German field data and experimental infection of cattle. Vet. Microbiol. 2010, 143, 189-195.

8. Flannery J., Sanz-Bernardo B., Ashby M., Brown H., Carpenter S., Cooke L., Corla A., Frost L., Gubbins S., Hicks H., Qureshi M., Rajko-Nenow P., Sanders C., Tully M., Breard E., Sailleau C., Zientara S., Darpel K., Batten C.: Evidence of reduced viremia, pathogenicity and vector competence in a reemerging European strain of bluetongue virus serotype 8 in sheep. Transbound. Emerg. Dis. 2019, 66, 1177-1185.

9. Jacquot M., Nomikou K., Palmarini M., Mertens P., Biek R.: Bluetongue virus spread in Europe is a consequence of climatic, landscape and vertebrate host factors as revealed by phylogeographic inference. Proc. R. Soc. B.: 2017, 284 , 20170919, doi: 10.1098/rspb2017.0919.

10. Kundlacz C., Caignard G., Sailleau C., Viarouge C., Postic L., Vitour D., Zientara S., Breard E.: Bluetongue virus in France: an illustration of the European and Mediterranean context since the 2000s. Viruses 2019, 11, 672, doi: 103390/v11070672. changes in the epidemiology of BT. 
11. Maan S., Maan N. S., Ross-Smith N., Batten C. A., Shaw A. E., Anthony S. J., Samuel A. R., Darpel K. E., Veronesi E., Oura C. A., Singh K. P., Nomikou K., Potgieter A. C., Attoui H., van Rooij E., van Rijn P., De Clercq K., Vandenbussche F., Zientara S., Breard E., Sailleau C., Beer M., Hoffman R., Mellor P. S., Mertens P. P. C.: Sequence analysis of bluetongue virus serotype 8 from the Netherlands 2006 and comparison to other European strains. Virology 2008, 377, 308-318.

12. MacLachlan N. J.: The pathogenesis and immunology of bluetongue virus infection of ruminants. Comp. Immunol. Microbiol. Infect. Dis. 1994, 17, 197-206.

13. MacLachlan N. J., Mayo C. E., Daniels P. W., Savini G., Zientara S., Gibbs E. P.: Bluetongue. Rev. Sci. Tech. 2015, 34, 329-340.

14. Mellor P. S., Boorman J. P. T., Wilkinson P. J., Martinez-Gomez F.: Potential vectors of bluetongue and African horse sickness viruses in Spain. Vet. Rec. 1983, 112, 229-230.

15. Mertens P. P. C., Maan N. S., Prasad G., Samuel A. R., Shaw A. E., Potgieter A. C., Anthony $S$. J., Maan S.: Design of primers and use of RT-PCR assays for typing European bluetongue virus isolates: differentiation of field and vaccine strains. J. Gen. Virol. 2007, 88, 2811-2823.

16. Mertens P. P. C., Maan N., Samuel A., Attoui H.: Genus Orbivirus, family Reoviridae, [in]: Fauquet C. M., Mayo M. A., Maniloff J., Desselberger U., Ball L. A. (eds.): Virus Taxonomy: Eighth Report of the International Committee of Taxonomy of Viruses, Elsevier Academic Press, San Diego, CA 2005, p. 466-483.

17. Mintiens K., Meroc E., Mellor P. S., Staubach C., Gerbier G., Elbers A. R., Hendrickx $G$., De Clercq K.: Possible routes of introduction of bluetongue virus serotype 8 into the epicentre of the 2006 epidemic in north-western Europe. Prev. Vet. Med. 2008, 87, 131-144.

18. Orłowska A., Trębas P., Smreczak P., Marzec C., Żmudziński J. F.: First detection of bluetongue virus serotype 14 in Poland. Arch. Virol. 2006, 161 , 1969-1972.
19. Purse B., Mellor P. S., Rogers D. J., Samuel A. R., Mertens P. P., Baylis M.: Climate change and the recent emergence of bluetongue in Europe. Nat. Rev. Microbiol. 2005, 3, 171-181.

20. Roy P., Marshall J. J., French T. J.: Structure of the bluetongue virus genome and its encoded proteins. Curr. Top. Microbiol. Immunol. 190, 162, 43-87.

21. Saegerman C., Berkvens D., Mellor P. S.: Bluetongue epidemiology in the European Union. Emerg. Infect. Dis. 2008, 14, 539-544.

22. Sailleau C., Breard E., Viarouge C., Gorlier A., Leroux A., Hirchaud E., Lucas P., Blanchard Y., Vitour D., Grandcollot-Chabot M., Zientara S.: Emergence of bluetongue virus serotype 4 in mainland France in November 2017. Transbound. Emerg. Dis. 2018, 65, 1158-1162.

23. Sailleau C., Breard E., Viarouge C., Vitour D., Romey A., Garnier A., Fablet A., Lowenski S., Gorna K., Caignard G., Pagneux C., Zientara S.: Re-emergence of bluetongue virus serotype 8 in France, 2015. Transbound. Emerg. Dis. 2017, 64, 998-1000.

24. Slingenbergh J., Gilbert M., De Balogh K., Wint W. G.: Ecological sources of zoonotic diseases. Rev. Sci. Tech. 2004, 23, 467-484.

25. Verwoerd D. W., Louw H., Oellermann R. A.: Characterization of bluetongue virus ribonucleic acid. J. Virol. 1970, 5, 1-7.

26. Vinomack C., Riviere J., Breard E., Viarouge C., Postic L., Zientara S. Vitour D., Belbis G., Spony V., Pagneux C., Sailleau C., Zanella G.: Clinical cases of bluetongue serotype 8 in calves in the 2018-2019 winter. Transbound. Emerg. Dis. 2020, 67, 1401-1405.

27. Walton T. E.: The history of bluetongue and a current global overview. Vet. Ital. 2004, 40, 31-38.

28. Wilson A., Mellor P.: Bluetongue in Europe: vectors, epidemiology and climate change. Parasitol. Res. 2008, 103, S69-S77.

29. Wilson A. J., Mellor P. S.: Bluetongue in Europe: past, present and future. Philos. Trans. R. Soc. Lond. B. Biol. Sci. 2009, 364, 2669-2681.

Corresponding author: Wiesław Niedbalski, PhD, DSc, Wodna 7, 98-220 Zduńska Wola, Poland; e-mail: wieslaw.niedbalski@piwzp.pl 